\title{
Formulation Design and In Vitro Evaluation of Carbamazepine Gastroretentive Floating Drug Delivery System for Oral Application
}

\author{
Md. Masud Kaisar BHUIYAN, Sujan BANIK, Md. Asif HASAN, Md. Selim REZA, Mohammad Salim HOSSAIN
}

\begin{abstract}
The aim of the study was to investigate the uses of hydrophilic polymers i.e. Methocel $\mathrm{K} 4 \mathrm{M}$ and Carbomer 971 to develop a gastroretentive floating drug delivery system containing Carbamazipine as a model drug. The effect of the polymers was evaluated in terms of physical characteristics, swelling properties, floating behavior and drug release profile. Floating lag time was found to be $4-136 \mathrm{sec}$ and total floating time was 6-18 $\mathrm{h}$ depending on the formulations. Drug release was studied
\end{abstract}

for $8 \mathrm{~h}$. Simulated drug release pattern in different kinetic model suggests that the mechanism controlling of the drug release from all formulations was the anomalous or non-Fickian. Along with more swelling capacity, carbopol 971 was able to retard the drug release more effectively than that of Methocel K4M based matrix.

Keywords: Carbamazepine, Methocel K4M, Carbopol 971, Buoyancy, GRDDS
Masud Kaisar BHUIYAN, Sujan BANIK, Asif HASAN, Mohammad Salim HOSSAIN

Department of Pharmacy, Noakhali Science and Technology University, Noakhali-3814, Bangladesh.

Selim REZA

Department of Pharmaceutical Technology, University of Dhaka, Bangladesh.

\section{Corresponding Author}

Mohammad Salim Hossain, PhD

Associate Professor

Cell: $+88-01711-200410$

Email:pharmasalim@yahoo.com

Submitted / Gönderilme: 07.08.2016

Accepted / Kabul: 08.09.2016

Revised / Düzeltme: 08.09.2016

\section{INTRODUCTION}

Among the drug delivery system, oral drug delivery is far the most popular route of drug delivery due to its patient compliance, ease of administration and cost effective manufacturing process (1). As most of the drugs are absorbed from the stomach or the upper part of the GI tract, novel oral controlled dosage form that is retained in the stomach is been a center of interest among industrial and academic researchers. One of the most popular approaches for attaining prolonged and predictable drug delivery in the stomach is gastro retentive drug delivery system (GRDDS) $(2,3)$. Generally, GRDDS is a controlled release drug delivery, which can significantly prolong the gastric residence time, which will increase the efficacy and bioavailability of drugs in the stomach. Among the various approaches of the GRDDS, floating drug delivery system (FDDS) has attained a great interest recently (4). Floating system involves the gas forming agent that helps in keeping the formulation in buoyant state and hence avoids its passage stomach facilitating the controlled release of drug from formulation $(5,6)$.

Carbamazepine (CBZ) is a drug widely used as antiepileptic in the therapy of psychomotor seizures and trigeminal neuralgia for its anticonvulsant and antineuralgic effects. Its popularity is related to its several beneficial properties, 
including efficacy in controlling different types of seizures (7). But CBZ is poorly soluble in water $\left(170 \mathrm{mg} / \mathrm{L}\right.$ at $\left.24^{\circ} \mathrm{C}\right)$ with erratic oral absorption and bioavailability less than $70 \%$. Gastric retention can improve the bioavailability for such a poorly water soluble drug. Thus prolonged gastric retention by GRFDDS improves bioavailability, reduces drug waste, and improves solubility for drugs that are less soluble in a high $\mathrm{pH}$ environment of small intestine as Carbamzepine is well absorbed in the stomach and upper portion of the small intestine.

Although several polymers like HPMC K4M, ethyl cellulose etc have been studied to formulate Carbamazepine gastroretentive floating drug delivery system (8) to improve its bioavailability, the objective of the present study was undertaken to develop a FDDS containing Carbamazepine as a model drug incorporated with two hydrophilic polymer Methocel K4M and Carbopol 971, and to observe the effect of these polymers and critical parameter on floating and drug release behavior of the system and selecting the best formulation based on optimizing techniques using evaluation parameters like floating lag time, total floating time and drug release profile.

\section{MATERIALS AND METHODS}

\subsection{Materials}

In this study Carbamazepine was used as a model drug obtained as a generous sample from Drug International Ltd, Bangladesh. Polymer Methocel K4M, Carbopol 971 were procured from BASF, Bangladesh Limited. Citric Acid Monohydrate, crospovidone, Avicel pH 101, Purified Talc and Magnesium stearate were also obtained as gift sample from University of Asia Pacific (UAP), Bangladesh. All other chemicals used were of analytical reagent grade and distilled water was used throughout the experiments.

\subsection{Preparation of floating matrix tablet}

Floating tablets of Carbamazepine were prepared by direct compression method. The composition of various formulations is shown in Table 1. The active ingredient and other excipients were weighed accurately for twenty five tablets according to the formulations and then blended together geometrically in a mortar pestle until homogenized. The granules were then sieved through mesh 40 . Finally the granules were weighed to adjust the final weight of individual tablet considering its loss during operational handling. The granules were compacted into tablets by direct compression at fixed compression force ( 5 tons) for specific period of time ( $2 \mathrm{~min}$ ) in the Perkin-Elmer laboratory hydraulic press. The amount of active ingredient was $100 \mathrm{mg}$ and the total weight of the tablets was $500 \mathrm{mg}$ for all of the 12 formulations. Formulated tablets were stored in airtight film container at room temperature $\left(25^{\circ} \mathrm{C}\right.$ to $\left.30^{\circ} \mathrm{C}\right)$ until further study. This method of tablet preparation has been carried out in accordance with our previously published papers (9-11) that provided reproducible experimental results in terms of invitro release.

Table 1. Formulation of Carbamazepine with two different polymers

\begin{tabular}{lcccccccccccc}
\hline Ingredients & F1 & F2 & F3 & F4 & F5 & F6 & F7 & F8 & F9 & F10 & F11 & F12 \\
\hline Carbamazepine & 100 & 100 & 100 & 100 & 100 & 100 & 100 & 100 & 100 & 100 & 100 & 100 \\
Methocel K4M & 80 & 100 & 120 & 140 & 160 & 200 & - & - & - & - & - & - \\
Carbopol 971 & - & - & - & - & - & - & 80 & 100 & 120 & 140 & 160 & 200 \\
NaHCO & 50 & 50 & 50 & 50 & 50 & 50 & 50 & 50 & 50 & 50 & 50 & 50 \\
Citric Acid & 50 & 50 & 50 & 50 & 50 & 50 & 50 & 50 & 50 & 50 & 50 & 50 \\
Crospovidone & 20 & 20 & 20 & 20 & 20 & 20 & 20 & 20 & 20 & 20 & 20 & 20 \\
Avicel PH 102 & 190 & 170 & 150 & 130 & 110 & 70 & 190 & 170 & 150 & 130 & 110 & 70 \\
Mg Stearate & 5 & 5 & 5 & 5 & 5 & 5 & 5 & 5 & 5 & 5 & 5 & 5 \\
Purified Talc & 5 & 5 & 5 & 5 & 5 & 5 & 5 & 5 & 5 & 5 & 5 & 5 \\
Total & $\mathbf{5 0 0}$ & $\mathbf{5 0 0}$ & $\mathbf{5 0 0}$ & $\mathbf{5 0 0}$ & $\mathbf{5 0 0}$ & $\mathbf{5 0 0}$ & $\mathbf{5 0 0}$ & $\mathbf{5 0 0}$ & $\mathbf{5 0 0}$ & $\mathbf{5 0 0}$ & $\mathbf{5 0 0}$ & $\mathbf{5 0 0}$ \\
\hline
\end{tabular}

*all the amounts are expressed in $\mathrm{mg}$ 


\subsection{Drug content and physical characterization}

The drug content of the formulated tablets was estimated using 50\% methanol solution as a solvent, and the sample was analyzed using double beam UV-Visible spectrophotometer (UV-1800, Shimadzu, Japan) at $284 \mathrm{~nm}$. All the formulated tablets were evaluated for hardness, friability, thickness, weight variation with regards their specification.

\subsection{In vitro buoyancy study}

The in vitro buoyancy was determined by floating lag time and the duration of floating of the developed tablets, Briefly, the tablets were placed in a $100 \mathrm{~mL}$ beaker containing $0.1 \mathrm{~N}$ $\mathrm{HCl}$. ( $\mathrm{pH}$ 1.2). The media was kept in stagnant condition and the temperature was maintained at $37^{\circ} \mathrm{C}$. The time required for the tablet to rise to the surface and float was determined as floating lag time and the floating durations were visually observed $(12,13)$

\subsection{Swelling index}

For the determination of swelling index, tablet from all formulations was placed in a beaker containing $100 \mathrm{~mL}$ of $0.1 \mathrm{~N} \mathrm{HCl}$ at room temperature. After each hour the tablet was removed from beaker and weighed again up to 5 hours (14). Tablets were removed carefully from the medium to ensure no loss of surface materials and excess surface water was wiped out with a tissue paper. The percentage swelling index was calculated using the following formula:

Swelling Index $=\frac{(\mathrm{Wt}-\mathrm{Wo})}{\mathrm{Wo}} * 100$

Where, $\mathrm{W}_{\mathrm{t}}=$ Weight of tablet at time $\mathrm{t} ; \mathrm{W}_{\mathrm{o}}=$ Initial weight of tablet

\subsection{In-vitro drug release studies}

The in-vitro release studies of the carbazmazepine from formulated tablets were performed using USP type-II apparatus (paddle method) for 8 hours at a stirring rate of $75 \mathrm{rpm}(8,15)$. The dissolution medium consisted of $0.1 \mathrm{~N}$ $\mathrm{HCl}$ acid media of $\mathrm{pH} 1.2,900 \mathrm{~mL}$, maintained at $37^{\circ} \mathrm{C} \pm$ $0.5^{\circ} \mathrm{C}$. An aliquot $(5 \mathrm{~mL})$ was withdrawn at specific time intervals which replaced by equivalent amount of media to maintain complete sink condition. The percent drug release was determined by UV-visible spectrophotometer (UV1800, Shimadzu, Japan) at $284 \mathrm{~nm}$. The release studies were conducted in triplicate.

\subsection{Analysis of release data}

To analyze the release kinetics of drug from the formulated floating matrix tablets, the obtained in vitro release data were fitted to different equations like zero order, first order, Higuchi's release and Korsmeyer-Peppas' models (16). The obtained dissolution data were also treated according to the well-known exponential equation, which is often used to describe the drug release behavior from polymeric systems introduced by Korsmeyer-Peppas et. al (16).

$\mathrm{M}_{\mathrm{t}} / \mathrm{M}_{\infty}=\mathrm{kt}^{\mathrm{n}}$

Where, $M_{t}$ is the amount of drug release at time $t, M_{\infty}$ is the amount of drug release after infinite time; $\mathrm{k}$ is a release rate constant incorporating structural and geometric characteristics of the tablet and $\mathrm{n}$ is the diffusional exponent indicative of the mechanism of drug release. A value of $n$ $=0.45$ indicates Fickian (case I) release, $>0.45$ but $<0.89$ for non-Fickian (anomalous) release and $>0.89$ indicates super case II type of release. Case II generally refers to the erosion of the polymeric chain and anomalous transport (non-Fickian) refers to a combination of both diffusion and erosion controlled-drug release (17).

Mean dissolution time (MDT) was calculated from dissolution data using the following equation (Mockel and Lippold) (18).

$\operatorname{MDT}=(\mathrm{n} / \mathrm{n}+1) \mathrm{k}^{-1 / \mathrm{n}}$

Where, $\mathrm{n}$ is the release exponent and $\mathrm{k}$ is the release rate constant.

\subsection{Statistical analysis}

To address the effect of polymer type on drug release, student t- test used applied.

$\mathrm{p}<0.05$ considered as statistically significant.

\section{RESULTS AND DISCUSSION}

\subsection{Physical characterization and drug content of floating tablets}

Table 2 is presented the values of physical parameters (thickness, diameter, hardness and friability), weight uniformity and drug content of all the formulated tablets. The thickness and diameter of the tablets were ranged from $3.04 \pm 0.04 \mathrm{~mm}$ to $3.51 \pm 0.02 \mathrm{~mm}$ and $13.29 \pm 0.02 \mathrm{~mm}$ to $13.54 \pm 0.01 \mathrm{~mm}$, respectively. Hardness of the tablets of all the formulations ranged from $12.66 \pm 0.19 \mathrm{kgf}$ to $26.93 \pm 0.44$ 
kgf. In the present study, the percentage friability for all the formulations was below $1 \% \mathrm{w} / \mathrm{w}$, indicating that the friability was within the prescribed limits. The weight variations of prepared tablets complied with the BP Pharmacopoeial specifications (19). The drug content in all the batches of carbamazepine floating tablet was found within the range of 95-105\% and this ensured the uniformity of drug content. So, all the formulated floating tablets showed acceptable physicochemical properties and complied with British Pharmacopoeial specifications of label content.

Table 2. Physicochemical properties of carbamazepine floating tablets of different formulations

\begin{tabular}{cccccccc}
\hline Formulation Weight variation $(\mathbf{m g})^{*}$ & Thickness $(\mathbf{m m})^{* *}$ & Diameter $(\mathbf{m m})^{* *}$ & Hardness $(\mathbf{K f})^{*}$ & ${\text { Friability }(\%)^{*}}^{*}$ Drug content $^{* *}(\%)$ \\
\hline F-1 & $490.13 \pm 0.45$ & $3.15 \pm 0.02$ & $13.5 \pm 0.02$ & $12.66 \pm 0.19$ & $0.09 \pm 0.04$ & $100.68 \pm 0.10$ \\
F-2 & $500.63 \pm 0.05$ & $3.51 \pm 0.02$ & $13.54 \pm 0.01$ & $13.17 \pm 0.47$ & $0.22 \pm 0.02$ & $103.37 \pm 0.01$ \\
F-3 & $498.43 \pm 0.17$ & $3.35 \pm 0.04$ & $13.50 \pm 0.02$ & $15.5 \pm 0.37$ & $0.32 \pm 0.10$ & $99.08 \pm 0.35$ \\
F-4 & $500.15 \pm 0.08$ & $3.34 \pm 0.02$ & $13.46 \pm 0.02$ & $15.69 \pm 0.46$ & $0.34 \pm 0.00$ & $99.61 \pm 0.19$ \\
F-5 & $500.00 \pm 0.08$ & $3.49 \pm 0.01$ & $13.48 \pm 0.03$ & $16.6 \pm 0.32$ & $0.27 \pm 0.04$ & $100.52 \pm 0.27$ \\
F-6 & $503.63 \pm 0.19$ & $3.32 \pm 0.01$ & $13.45 \pm 0.02$ & $20.26 \pm 0.29$ & $0.28 \pm 0.04$ & $103.40 \pm 0.15$ \\
F-7 & $485.23 \pm 0.12$ & $3.07 \pm 0.09$ & $13.33 \pm 0.02$ & $21.56 \pm 0.51$ & $0.30 \pm 0.02$ & $100.36 \pm 0.02$ \\
F-8 & $487.02 \pm 0.10$ & $3.05 \pm 0.04$ & $13.29 \pm 0.04$ & $23.46 \pm 0.30$ & $0.19 \pm 0.02$ & $95.43 \pm 0.89$ \\
F-9 & $482.73 \pm 0.18$ & $3.04 \pm 0.04$ & $13.29 \pm 0.02$ & $24.96 \pm 0.60$ & $0.19 \pm 0.09$ & $95.29 \pm 0.55$ \\
F-10 & $506.42 \pm 0.13$ & $3.19 \pm 0.04$ & $13.42 \pm 0.03$ & $26.20 \pm 0.71$ & $0.22 \pm 0.04$ & $98.47 \pm 0.41$ \\
F-11 & $490.57 \pm 0.09$ & $3.10 \pm 0.05$ & $13.37 \pm 0.03$ & $26.93 \pm 0.44$ & $0.33 \pm 0.02$ & $98.20 \pm 0.65$ \\
F-12 & $495.57 \pm 0.05$ & $3.11 \pm 0.04$ & $13.36 \pm 0.04$ & $26.87 \pm 0.44$ & $0.26 \pm 0.06$ & $96.90 \pm 0.82$ \\
\hline
\end{tabular}

The values are expressed as mean $\pm S E M$; ${ }^{*}$ and ${ }^{* *}$ indicates $n=10$ and $n=3$ respectively

\subsection{In vitro buoyancy study}

In-vitro buoyancy study was carried out for determining floating lag time and floating duration of tablet by placing tablet in $100 \mathrm{~mL}$ beaker containing $0.1 \mathrm{~N} \mathrm{HCl}$. In the present study, floating lag time of 12 formulations was found to be in the range of 4.12 to $136.2 \mathrm{sec}$ and floating duration was found to be in the range of 6 to $18 \mathrm{~h}$. It was also observed that buoyancy lag time is elevated for the formulations containing small amount of retardant polymer like Methocel K4M and total floating time is improved when the amount of Methocel K4M is gradually increased (Table 3). But buoyancy lag time is elevated for the formulation containing small amount of retardant polymer like Carbomer 971 and total floating time is reduces when the amount of Carbomer 971 is gradually increased (Table 3). There was an increase in the buoyancy lag time which could be attributed to the fact that tablets containing low viscosity Methocel K4M swell rapidly than tablets with high viscosity Carbomer 971. Also higher floatation time of these tablets causes slower $\mathrm{CO}_{2}$ release because of the presence of the effervescent agents within the Methocel matrix.
Table 3. In-vitro buoyancy study of formulations containing Methocel K4M and Carbopol 971

\begin{tabular}{ccc}
\hline Formulation & $\begin{array}{c}\text { Buoyancy lag time } \\
(\mathbf{s e c})\end{array}$ & $\begin{array}{c}\text { Total floating time } \\
\text { (hrs) }\end{array}$ \\
\hline F-1 & 4.12 & $>8$ \\
F-2 & 7.31 & $>9$ \\
F-3 & 6.25 & $>11$ \\
F-4 & 6.24 & $>12$ \\
F-5 & 7.31 & $>14$ \\
F-6 & 20.31 & $>18$ \\
F-7 & 81.2 & $>12$ \\
F-8 & 136.2 & $>10$ \\
F-9 & 94.5 & $>10$ \\
F-10 & 95.1 & $>8$ \\
F-11 & 73.1 & $>6$ \\
F-12 & 87.2 & $>6$ \\
\hline
\end{tabular}

\subsection{Swelling index}

Swelling of tablet involves the incorporation of a liquid 
resulting in an increase in tablet density. Liquid uptake by the particles may be due to the saturation of capillary spaces within the particles or hydration of macromolecule. The liquid enters the particles through pores and bind to large molecule; breaking the hydrogen bond and resulting in the swelling of particle. The extent of swelling was measured in terms of weight gain by the tablet. Swelling index of formulations F7 to F12 containing polymer Carbomer 971 was found to be more than formulations F1 to F6 containing polymer Methocel K4M (Table 4). From the results of swelling study it is clear that the percentage swelling increased as the time passes because the high viscosity polymer (Carbomer 971) absorbed more water due to its hydrophilic nature than low viscosity polymer (Methocel K4M) and swell.

Table 4. Swelling index study of formulations containing Methocel K4M and Carbopol 971

\begin{tabular}{|c|c|c|c|c|c|}
\hline \multirow[b]{2}{*}{ Formulation } & \multicolumn{5}{|c|}{ Swelling Index (\%) } \\
\hline & 1h & $2 \mathrm{~h}$ & $3 \mathrm{~h}$ & $4 \mathrm{~h}$ & $5 \mathrm{~h}$ \\
\hline F-1 & 22.51 & 35.88 & 44.01 & 56.33 & 63.82 \\
\hline F-2 & 16.30 & 34.55 & 43.68 & 64.12 & 80.06 \\
\hline F-3 & 15.86 & 34.04 & 43.13 & 63.50 & 79.38 \\
\hline F-4 & 63.19 & 82.38 & 90.65 & 97.63 & 97.97 \\
\hline F-5 & 75.00 & 97.19 & 99.20 & 104.10 & 105.10 \\
\hline F-6 & 64.03 & 97.62 & 107.57 & 119.55 & 120.17 \\
\hline F-7 & 59.59 & 71.93 & 85.50 & 95.59 & 116.07 \\
\hline F-8 & 80.76 & 103.68 & 105.76 & 110.81 & 111.84 \\
\hline F-9 & 71.47 & 86.23 & 100.60 & 114.47 & 142.32 \\
\hline F-10 & 71.33 & 85.73 & 101.25 & 115.72 & 148.61 \\
\hline F-11 & 72.44 & 91.79 & 112.85 & 131.10 & 166.80 \\
\hline F-12 & 77.43 & 97.96 & 114.26 & 144.40 & 169.65 \\
\hline
\end{tabular}

\subsection{Release kinetic studies}

The dissolution data of all formulations were fitted to various mathematical models such as zero-order, first-order, Higuchi's, Korysmeyer and Peppas' model to know which mathematical model will best fit for the obtained release profile. The cumulative percentage of drug release after 8 hours of all formulations and the release parameters of all formulations are presented in Table 5. The release profile of promising batch, F4, fitted best to zero order with $r^{2}$ value of 0.998 (Figure 1). Based on the ' $n$ ' values ranging from $0.45<$ $n<0.89$ the drug release was found to follow anomalous or non-Fickian and Case II type release. This value indicates a coupling of the diffusion and erosion of the polymeric chain mechanism and the drug release was controlled by more than one process. This finding was in accordance with other reported works $(20,21)$.

Table 5. Cumulative percentage release $(\mathrm{CPR})$ and release kinetics parameter of formulated floating tablets of CBZ

\begin{tabular}{|c|c|c|c|c|c|c|}
\hline \multirow[b]{2}{*}{ Formulation } & \multicolumn{2}{|r|}{ Zero order } & \multirow{2}{*}{$\begin{array}{c}\text { First order } \\
\qquad \mathrm{R}^{2}\end{array}$} & \multirow{2}{*}{$\begin{array}{c}\text { Higuchi's } \\
\mathrm{R}^{2}\end{array}$} & \multicolumn{2}{|c|}{ Korsmeyar-Peppas' } \\
\hline & $\mathrm{CPR}^{\star}$ & $\mathrm{R}^{2}$ & & & $\mathrm{R}^{2}$ & $\mathrm{n}$ \\
\hline F1 & $81.09 \pm 1.19$ & 0.781 & 0.92 & 0.946 & 0.946 & 0.459 \\
\hline F2 & $75.21 \pm 1.17$ & 0.864 & 0.965 & 0.983 & 0.993 & 0.471 \\
\hline F3 & $63.99 \pm 1.07$ & 0.908 & 0.971 & 0.997 & 0.998 & 0.465 \\
\hline $\mathrm{F} 4$ & $45.97 \pm 1.28$ & 0.998 & 0.996 & 0.941 & 0.994 & 0.838 \\
\hline F5 & $44.32 \pm 1.17$ & 0.988 & 0.972 & 0.895 & 0.972 & 0.839 \\
\hline F6 & $34.01 \pm 1.01$ & 0.986 & 0.992 & 0.971 & 0.994 & 0.668 \\
\hline F7 & $19.23 \pm 2.90$ & 0.976 & 0.982 & 0.976 & 0.995 & 0.798 \\
\hline F8 & $21.29 \pm 1.22$ & 0.956 & 0.997 & 0.956 & 0.994 & 0.762 \\
\hline F9 & $16.70 \pm 3.03$ & 0.964 & 0.996 & 0.964 & 0.999 & 0.789 \\
\hline F10 & $19.84 \pm 1.07$ & 0.966 & 0.994 & 0.966 & 0.997 & 0.841 \\
\hline F11 & $18.94 \pm 0.95$ & 0.963 & 0.996 & 0.963 & 0.998 & 0.894 \\
\hline F12 & $18.69 \pm 1.18$ & 0.995 & 0.997 & 0.954 & 0.996 & 0.914 \\
\hline
\end{tabular}

${ }^{\star} \mathrm{CPR}$ of drug after 8 hours, The values are expressed as mean \pm SEM $(\mathrm{n}=3)$; 

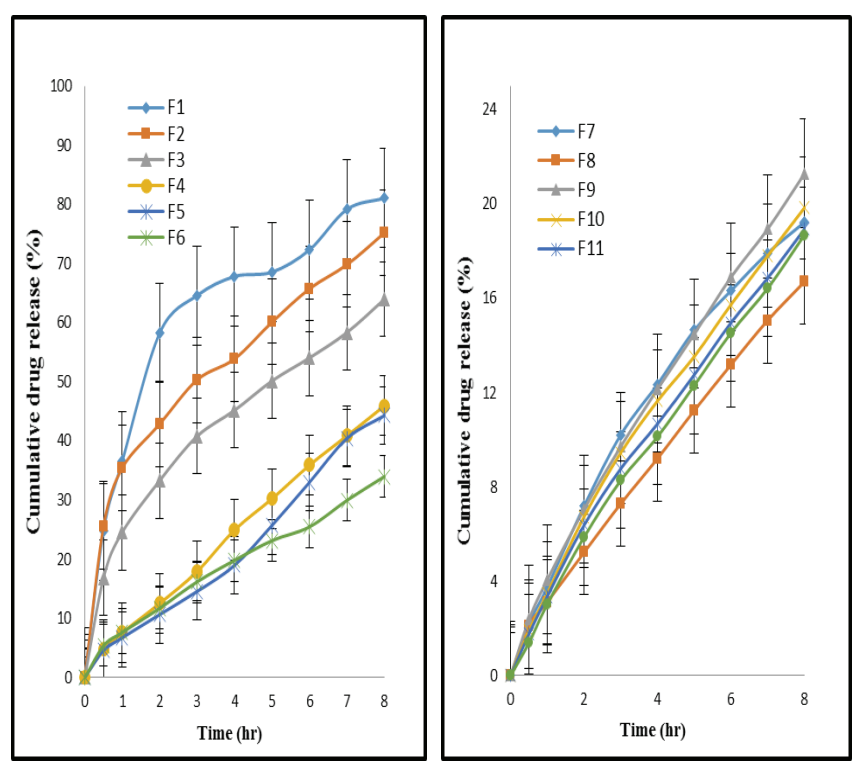

Figure 1. Dissolution release model of carbamazepine floating tablets containing (a) Methocel K4M and (b) Carbopol 971

In this present study, two polymers Methocel K4M and Carbopol 971 were used in formulated CBZ floating tablets to evaluate the effect on release profiles due to the polymer type. Methocel is a hydrophilic polymer and most widely used for controlled-release drug formulations and carbopols are synthetic high-molecular-weight polymers of acrylic acid and they are readily water-swellable polymers.

The release of drug from Methocel K4M based floating tablets was greater than Carbopol based tablets. In case of both polymers, drug release decreased with the increase of concentration of polymer i.e higher the polymer concentration lowers the drug release. Between these two polymers, Carbopol 971 was statistically more effective $(\mathrm{p}<0.05)$ to retard the drug release than Methocel K4M. This could be explained due to the formation of more viscous layer (gel layer) in carbopol containing formulation upon exposure to aqueous medium by undergoing rapid hydration and chain relaxation and this gel layer acts as the barrier to release of drug and as a result drug release was more prolonged (Figure 2). The data revealed that, $\mathrm{T}_{25 \%}, \mathrm{~T}_{50 \%}$ and $\mathrm{T}_{75 \%}$ values were altered due to the change of the quantity of Methocel K4M and Carbopol 971 in the floating tablets (Table 6). In all these formulations the values of $\mathrm{T}_{50 \%}$ and $\mathrm{T}_{75 \%}$ are larger for those formulations that contain larger quantities of Methocle K4M and Carbopol 971. This observation draws an important conclusion that the increase of Methocle K4M and Carbopol 971 content causes the decrease of rate and extent of CBZ release. Carbopol 971 containing formaulation showed higher $\mathrm{T}_{50 \%}$ values than that of Methocel K4M based formulation.

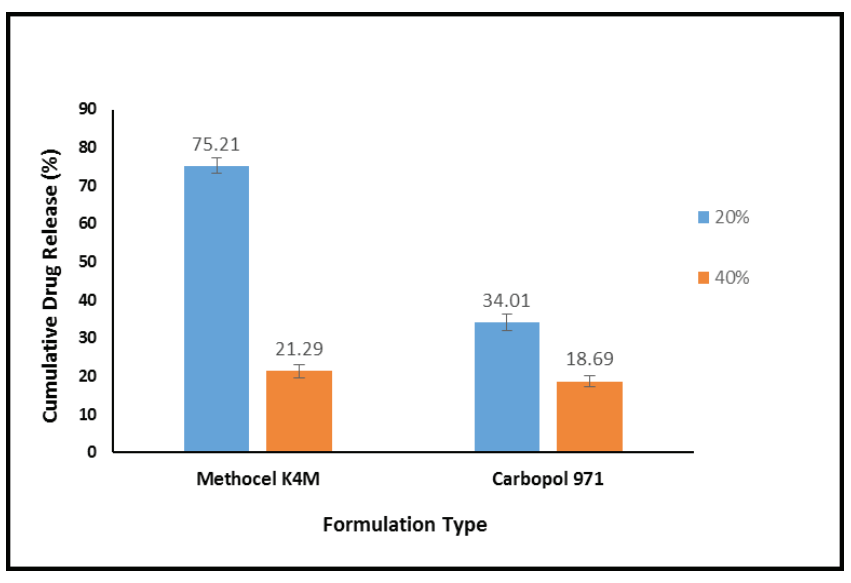

Figure 2. Comparison of drug release rate at different concentrations (20\% and 40\%) of Methocel K4M and Carbopol 971.

Mean Dissolution Time (MDT) value is used to characterize the drug release rate from the dosage form and the retarding efficacy of the polymer. A higher value of MDT indicates a higher drug retarding ability and vice-versa. The MDT value was found to below for formulation F2 and high for formulation F8 (Table 6). In other words, the formulations containing higher percentage of polymer exhibited a higher value of MDT. MDT values for Carbopol 971 based matrix supported the notion of retarding drug release more effectively than that of Methocel K4M based matrix.

Table 6. Required time for $25,50,75$ percentage of drug release and mean dissolution time

\begin{tabular}{cllll}
\hline Formulations & $\mathbf{T}_{25 \%}$ & $\mathrm{~T}_{50 \%}$ & $\mathrm{~T}_{75 \%}$ & MDT (hr) \\
\hline F1 & 0.621 & 1.512 & 2.402 & 5.53 \\
F2 & 0.776 & 1.786 & 2.796 & 5.08 \\
F3 & 1.075 & 2.215 & 3.354 & 6.89 \\
F4 & 1.874 & 3.352 & 4.829 & 9.57 \\
F5 & 2.021 & 3.590 & 5.158 & 11.04 \\
F6 & 2.341 & 4.430 & 6.518 & 17.90 \\
F7 & 3.681 & 7.068 & 10.454 & 25.87 \\
F8 & 4.435 & 8.531 & 12.628 & 38.03 \\
F9 & 3.534 & 6.737 & 9.940 & 25.27 \\
F10 & 3.734 & 7.127 & 10.519 & 24.60 \\
F11 & 3.926 & 7.503 & 11.079 & 26.06 \\
F12 & 4.010 & 7.633 & 11.255 & 22.98 \\
\hline
\end{tabular}




\section{CONCLUSION}

Swellable/floatable in-vitro buoyancy system for gastroretentive drug delivery has been developed using hydrophilic polymer Methocle K4M and Carbopol 971. The study revealed that both the polymer (Methocel K4M and Carbopol 971) has the capacity to retard the drug release from matrix in a concentration dependent fashion. Carbopol 971 has the grater ability to retard the drug release than that of Methocel K4M. This phenomenon may be governed by the

Midede kalış süresini uzatan yüzen karbamazepin tabletlerinin formülasyonu ve in vitro değerlendirilmesi

\section{ÖZ}

$\mathrm{Bu}$ çalışmanın amacı, etken madde olarak karbamazepin içeren midede kalış süresini uzatan yüzen bir model tablette Metosel K4M and Karbomer 971 gibi hidrofilik polimerlerin etkinliklerinin değerlendirilmesidir. Polimerlerin etkinlikleri; fiziksel özellikleri, şişme özellikleri, yüzme yetenekleri ve ilaç salım profilleri açısından değerlendirilmiştir. Tabletlerin swelling properties of the polymers. Carbopol 971 showed the more swelling capacity than that of Methocel K4M. Along with the retardant ability of drug release, both the polymer showed a considerable potential of its use as matrix former for floating drug delivery system. Drug was diffused out from the matrix with an anomalous non Fickian fashion.

\section{CONFLICT OF INTEREST}

No conflict of interest

\section{REFERENCES}

1. Sankar V, Hearnden V, Hull K, Juras DV, Greenberg M, Kerr AR, Lockhart PB, Sastry SV. Atenolol gastrointestinal therapeutic system I. Screening of formulation variables. Drug Dev Ind Pharm 1997; 23: 157-65.

2. Bardonnet P, Faivre V, Pugh W. Gastroretentive dosage forms: overview and special case of Helicobacter pylori. J Control Rel 2006; 111: 1-18.

3. Klausner EA, Eran L, Michael F. Expandable gastroretentive dosage forms. J Control Rel 2003; 90: 143-62.

4. Awasthi R, Kulkarni GT. Development of novel gastroretentive floating particulate drug delivery system of gliclazide. Curr Drug Deliv 2012; 9: 437-51.

5. Whitehead L, Fell JT, Sharma HL. Floating dosage forms: an in vivo study demonstrating prolonged gastric retention. J Control Rel 1998; 55: 3-12.

6. Pawar VK, Kansal S, Garg G, Awasthi R, Singodia D, Kulkarni GT. Gastroretentive dosage forms: A review with special emphasis on floating drug delivery systems. Drug Deliv 2011; 18: 97-110.

7. Carbamazepine, package insert. Available at: www.pharma. us.novartis.com/product/pi/pdf/tegretol.pdf. [Accessed on June 15, 2016].

8. Patel DM, Patel NM, Pandya NN, Jogani PD. Gastroretentive drug delivery system of carbamazepine: Formulation optimization using simple lattice design: A technical note. AAPS Pharm Sci Tech 2007; 8: Article 11. formülasyonlarına bağlı olarak yüzmeye başlama öncesindeki gecikme süreleri 4-136 saniye, toplam yüzme süreleri 6-18 saat olarak bulunmuştur. Tabletlerden etken madde salımı 8 saatlik bir zaman dilimi için çalışılmıştır. Simulasyon ile oluşturulan farklı ilaç salım kinetik modelleri ile yapılan çalışmalar sonucunda; hazırlanan bütün formülasyonların ilaç salım özelliklerinin özdeş olmadığı veya Fick yasasına uymadığ tespit edilmiștir. Karbopol 971'in, Metosel K4M'ye kıyasla daha yüksek şişme kapasitesine sahip olması nedeniyle ilaç salım süresini daha etkili şekilde uzattığı tespit edilmiştir.

Anahtar kelimeler: Karbamazepin, Metosel K4M, Karbopol 971, Yüzebilme özelliği, GRDDS.
9. Hasan MA, Sultana S, Banik S, Bhuiyan MMK, Reza MS, Hossain MS. Formulation and in vitro characterization of hydrochlorothiazide gastroretentive floating drug delivery system. Dhaka Univ J Pharm Sci 2015; 14: 163-70.

10. Hossain MS, Banik S, Islam MS. Formulation design and characterization of Kollidon SR based trimetazidine dihydrochloride matrix tablets. Ind J Pharm Edu Res 2012; 46: 136-44.

11. Akter M, Banik S, Hossain MS. In vitro evaluation of oral extended release drug Delivery system for metoprolol succinate using Kollidon SR. J App Pharm Sci 2012; 2: 188-92.

12. Rosa M, Zia H, Rhodes T. Design and testing in vitro of a bioadhesive and floating drug delivery system for oral application. Int J Pharm 1994; 105: 65-70.

13. Tadros MI. Controlled-release effervescent floating matrix tablets of ciprofloxacin hydrochloride: Development, optimization and in-vitro in-vivo evaluation in healthy human volunteers. Eur J Pharm Biopharm 2010;74: 332-9.

14. Colombo P, Bettini R, Santi P, Ascentiis DeA, Peppas NA. Analysis of the swelling and release mechanisms from drug delivery systems with emphasis on drug solubility and water transport. J Control Rel 1996; 39: 231-7.

15. Costa P, Sousa JM. Modeling and comparison of dissolution profiles. Eur J Pharm Sci 2001; 13: 123-33.

16. Korsmeyer RW, Gurny R, Peppas NA. Mechanism of solute release from porous hydrophilic polymers. Int J Pharm 1983; 15: 25-35.

17. Shato H, Miyagawa Y, Okabe T. Dissolution mechanism of 
diclofenac sodium from wax matrix granules. J Pharm Sci 1997; 86: 929-34.

18. Mockel JE, Lippold, BC. Zero-order release from hydrocolloid matrices. Pharm Res 1993; 10: 1066-70.

19. British Pharmacopoeia $7^{\text {th }}$ ed, 2013. Appendix XII C. Consistency of Formulated Preparations.
20. Ritger PL, Peppas NA. A simple equation for description of solute release II. Fickian and anomalous release from swellable devices. J Control Rel 1987; 5: 37-42.

21. Jindal S, Jindal K, Gupta GD, Rajeev Garg R, Awasth R. Gastroretentive floating tablets of ofloxacin: Study the effect of formulation variables. Marmara Pharm J 2016; 20: 100-10. 